\title{
鋼板の打抜き解析精度に及ぼす解析条件の影響
}

\section{Effects of Analysis Conditions on Precision for Blanking Press Analysis of Steel Sheet}

\author{
学 ○中野裕文（富山県立大学・院）松井裕明（田中精密工業） \\ 正 森 孝男 (富山県立大学・I)
}

Hirofumi NAKANO, Toyama Prefectural University, Kurokawa, Imizu-shi, Toyama Hiroaki MATSUI, TANAKA SEIMITSU KOGYO CO.,LTD, Shinjyo, Toyama-shi, Toyama Takao MORI, Toyama Prefectural University, Kurokawa, Imizu-shi, Toyama

Key Words: Blanking Press Analysis, Steel

\section{1. 緒言}

自動車部品は，打抜き加工で製造されることが多く，薄鋼 板を打抜いた後，そおれらを重ね，かしめ接合により組み立 てる場合がある.このような場合，薄鋼板の打抜き部分の形 状や寸法がかしめ接合に影響を及ばす，そのため, 有限要素 法解析で打抜き形状が予測できれば，ポンチとダイのクリア ランスなどの打抜き条件を求めることが可能となる.

本研究は, 有限要素法解析により最適な打抜き条件を求め ることを目的とする.本報告では, その第1ステップとして, 単純な薄板鋼板モデルの打ち抜き解析を行い，要素の破壞条 件や要素分割が解析精度および解析時間に及ぼす影響を検 討する.

\section{2. 解析方法}

\section{2-1 解析モデル}

本研究では, 最も単純な円板の打抜き解析を行う。解析は軸 対称問題として，打抜き部の解析モデルを Fig.1 に示す. 解 析モデルは，薄鋼板，ポンチ，ダイ，ホルダーからなる．薄 鋼板の板厚は $0.2 \mathrm{~mm}$, ポンチ半径が $0.55 \mathrm{~mm}$, ポンチとダイ のクリアランスが $0.005 \mathrm{~mm}$ である. 解析モデルの要素分割 図を Fig.2に示す.メッシュサイズはポンチ, ホルダー, ダ イは $0.05 \mathrm{~mm}$ ，シートの打拔き部（クリアランス部）は $0.001 \mathrm{~mm}$, シートのそれ以外の部分は $0.025 \mathrm{~mm}$ とした. 当初, 打抜き部近傍を $0.001 \mathrm{~mm}$ の要素分割としたが，打抜き時の き裂進展が薄鋼板の中心部へ向かってしまうため，打抜き部 のみを細分割した. ポンチ, ホルダー及びダイは剛体とした.

\section{2-2 解析条件}

解析には汎用有限要素法ソフトLS-Dyna を用いた. 薄鋼板

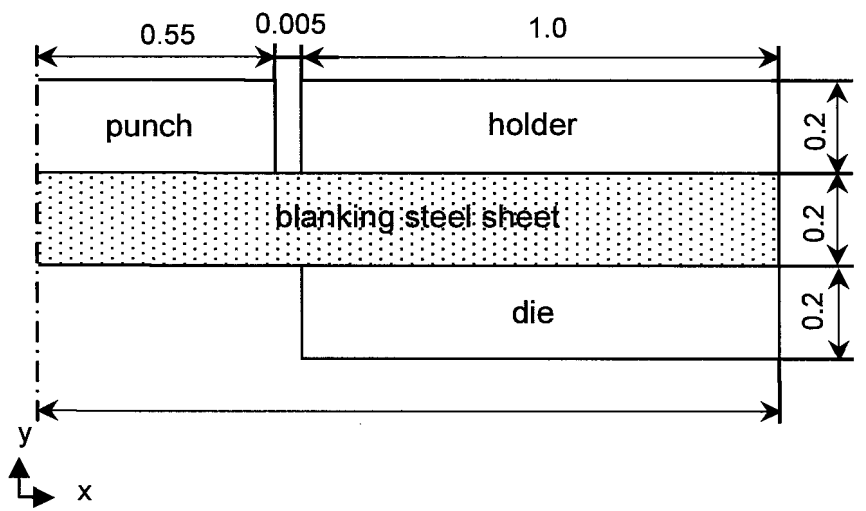

Fig.1. Analysis model.
の材料特性は, 縦弹性係数を $206 \mathrm{GPa}$, 質量密度を $7800 \mathrm{~kg} / \mathrm{m}^{3}$, ポアソン比を 0.3 とし, 降伏応力を $380 \mathrm{MPa}$, 降伏後の応力 一ひずみ関係を Fig.3 に示す直線とした. ポンチ, ホルダー, ダイと薄鋼板の間で接触を考慮した. 解析時間は $1.0 \mathrm{e}-05$ 秒 であり，ポンチの速度は解析開始から解析終了まで 3000 $\mathrm{mm} / \mathrm{s}$ で一定とする.

打抜きによるき裂発生は，アダプティブメッシュによる方 法, 要素を消去する方法を用いたが, アダプティブメッシュ による方法では, 要素再分割によって節点の位置が乱れ, 解 析結果として適切な結果が得られなかった. そのため,まず, 要素の相当塑性ひずみの值が限界值になったときに要素を 消去する方法で行った.この限界相当塑性ひずみを $\varepsilon_{c r}=0.1$, $0.5,1.0$ の 3 通りとし, 破断形状, き裂進展の様子, 相当応

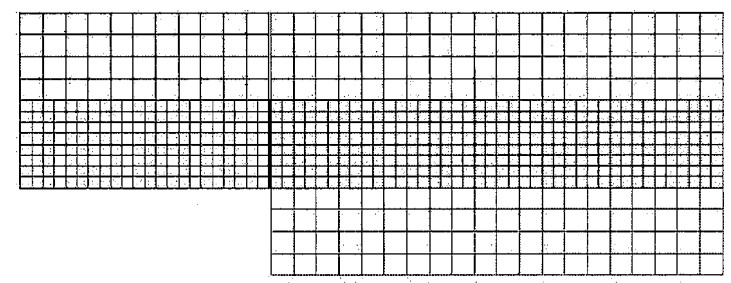

Fig.2. Mesh model.

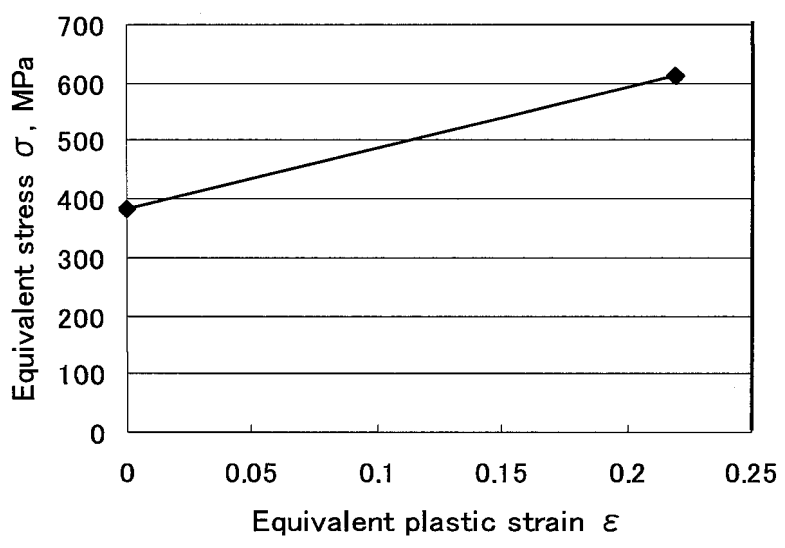

Fig.3. The relationship between Equivalent stress and Equivalent plastic strain. 
力, 塑性ひずみなどについて検討する.

\section{3. 解析結果と考察}

解析結果の一例として, Fig.4，Fig.5，Fig.6 にそれぞれ限 界相当塑性ひずみが $\varepsilon_{c r}=0.1,0.5,1.0$ の場合の打拔き部近 傍の相当応力分布とき裂進展状況を示寸. 図中の矢印はき裂 が進展している方向を表している，また，各図において，図 (a)は破断前, 図(b)は破断後を示している.

Fig.4においてき裂は, はじめに右上と左下から進展する. しかし，き裂の進展とともに，上方，下方のき裂とも，打抜 き部において, き裂発生位置と反対側に達し, 鋼板中央部で はき裂が水平になり, その近傍の要素も消滅し, 穴が空いて いる.このき裂進展による破断状況は実際の破断とは異なる. Fig.5 においてき裂は，左上と右下よりき裂が上下方向にま っすぐ進展する. そして中央部付近でき裂が階段状に進展し， 破断に至る.この場合の破断状況は実際とは一致しないが, $\varepsilon_{c r}=0.1$ に比較すると実際の破断状況に近い. Fig.6において, 結果は Fig.5 と同様な結果が得られた。しかし， $\varepsilon_{\mathrm{pl}}$ が 0.1 か ら 1.0 になるにつれて計算時間は遅くなる傾向がみられた。

Fig.7に，当初行った打抜き部近傍を細分割したモデルの 解析結果の一例を示す. 図中の矢印はき裂の伝わる方向を示 している. このモデルの問題点は，ポンチの下にき裂が進展

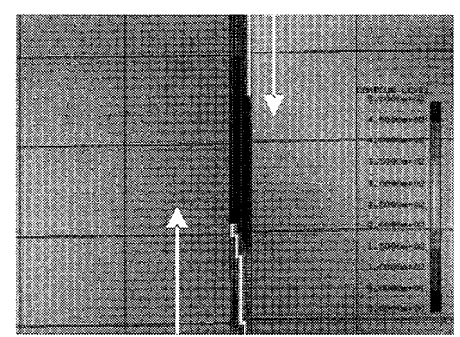

(a) Before rupture.

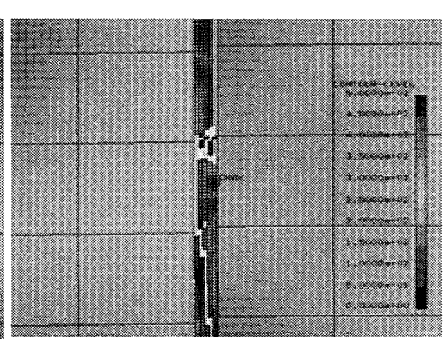

(b) After rupture.
Fig.4. Condition of crack propagation. $\left(\bar{\varepsilon}_{\mathrm{pl}}=0.1\right)$

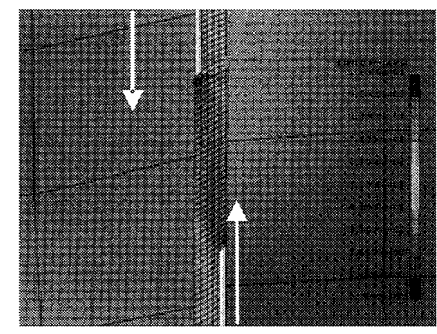

(a) Before rupture.

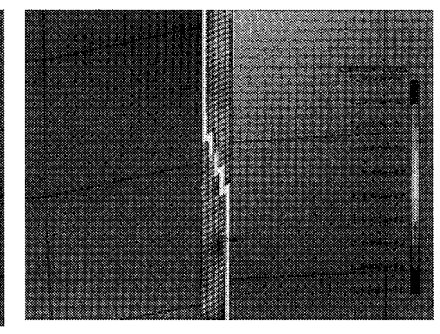

(b) After rupture.
Fig.5. Condition of crack propagation. $\left(\bar{\varepsilon}_{\mathrm{pl}}=0.5\right)$

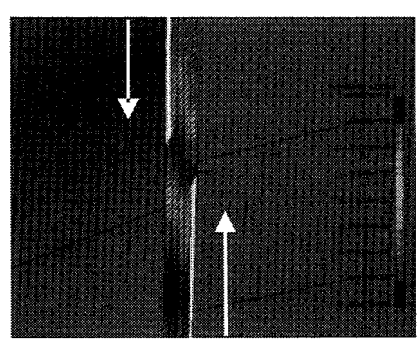

(a) Before rupture.

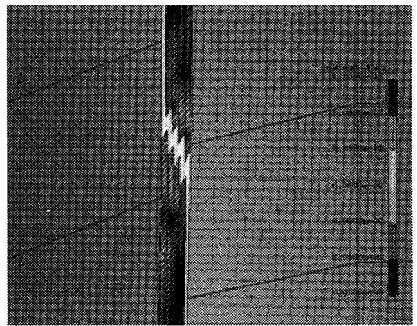

(b) After rupture.
Fig.6. Condition of crack propagation. $\left(\bar{\varepsilon}_{\mathrm{pl}}=1.0\right)$
することである.このようにき裂が進展する原因としては， ポンチ角部直下では, せん断応力とともに圧縮応力が作用し， 相当塑性ひずみが大きくなるためではないかと考えられる.

また, ポンチの下部への移動に伴い，き裂の右側の破断面 がポンチの角により削られてしまう。このモデルの要素数は 約 44000 であったのに対し，打抜き部のみを細分割する現行 モデルは約 4000 でるため計算時間は約 $45 / 1$ になっている.

Fig. 8 は, 限界相当塑性ひずみに対するポンチ反力の最大 值を示す．限界相当塑性ひずみが $\varepsilon_{c r}=0.5,1.0$ の場合は，限 界相当塑性ひずみ $\varepsilon_{c r}=0.1$ に比べてポンチ反力の最大值が高 く,193N となっている. 解析開始から約 $4.0 \mathrm{e}-08 \mathrm{~s}$ 後にポンチ 反力は最大となる.

\section{4. 結言}

有限要素法解析により最適な打抜き条件を求めることを 目的とし, その第 1 ステップとして, 単純な薄板鋼板モデル の打ち抜き解析を行い, 要素の破壊条件や要素分割が解析精 度および解析時間に及ぼす影響を検討した。そその結果，アダ プチブメッシュを用いたき裂進展法では再分割した要素の 乱れが大きく, 適切な解が得られず, 相当塑性ひずみが限界 値に達したときに要素を消滅させるき裂進展法が適してい ることを得た. 要素を消滅させるき裂進展法では, 限界相当 塑性ひずみ $\varepsilon_{c r}=0.1$ のときは, 破断状況が実際と異なるが, $\varepsilon_{c r}=0.5$ では実際にやや近いものとなった. さらに，打抜き 部の破断形状を実際と近づけるには, 打抜き部の要素サイズ をさらに細かくした場合について検討を進める必要がある.

\section{参考文献}

省略

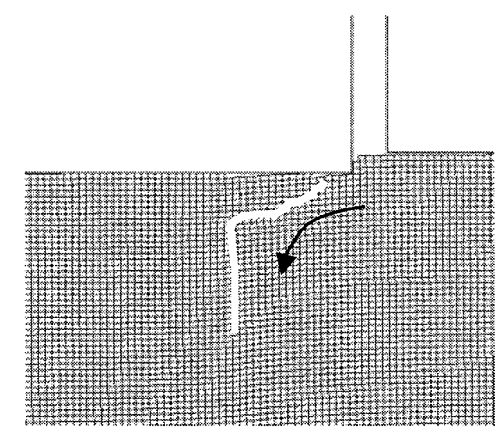

Fig.7. The failed analysis result.

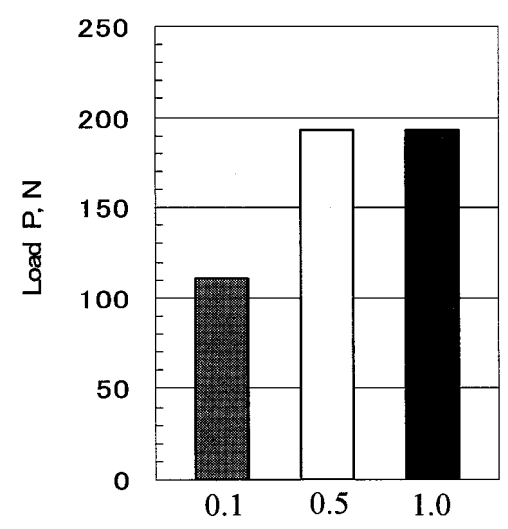

Equivalent Plastic Strain

Fig.8. The relationship Load and Equivalent Plastic Strain. 